\title{
IMPACT OF SCHOOL POLICY IMPLEMENTATION ON SNACK CONSUMPTION AMONG PRIMARY SCHOOL STUDENTS IN DEPOK, WEST JAVA
}

\author{
Untung Setiawan'), Evi Martha²), Kartika Setyaningsih Sunardi'), \\ Ade Tzarina Prisella Purnamasari'), Farida Naftalin'), Eka Triana', \\ Lidya'), Leti Ratna Kusumawati1) \\ ${ }^{1)}$ Masters Program in Public Health, Faculty of Public Health, Universitas Indonesia \\ 2)Department of Health Policy and Administration, Faculty of Public Health, \\ Universitas Indonesia
}

\begin{abstract}
Background: School snacks are an issue that needs public attention, especially parents, educator, and school manager. Snacks sold outside the school are often unhealthy and potentially may cause poisoning. A preliminary study at Beji 6 Public Primary School, Depok, West Java, showed that a lot of unhealthy snacks were sold near schools. This study aimed to examine the impact of school policy implementation on snack consumption among primary school students in Depok, West Java.

Subjects and Method: A qualitative study was conducted at Beji 6Primary School, Depok, West Java, in May 2019. Six informants were selected in this study, including school principal, teacher, students, school guard, school canteen sword, and snack trader outside school. The data were analyzed descriptively.

Results: School policy had only been implemented for the $6^{\text {th }}$ grade students. The canteen at the Beji 6 Primary School, Depok, was lacking in space. Teachers, students, school guard, snack traders, were not aware of the school policy on snack consumption. School canteen had never received training on healthy school canteen. The school policy was not reinforced because the school did not want to stop the income of the snack traders. School had coordinated with snack traders outside the school about the need to sell food with a healthy and safe process. Local health office and national agency of drug and food control had examined food sample.

Conclusion: Implementation of school policy on snack consumption at Beji 6 Primary School, Depok, West Java, is limited. School management and local government need to pay attention on school canteen.
\end{abstract}

Keywords: school policy, snack, primary school students

\section{Correspondence:}

Untung Setiawan. Masters Program in Public Health, Faculty of Public Health, Universitas Indonesia, Depok, West Java. Email: untungbintaro@gmail.com. Mobile: 08562226094.

\section{BACKGROUND}

Children in Elementary School age are a group of future generations who have the potential to advance a nation in the future. The formation of a human quality starts from the children in elementary school. So far there are still many school snacks that are not guaranteed health and have the potential to cause poisoning. With so many foods containing dangerous chemicals on the market, school canteens, and food ven- dors around the school are important agents that can make students consume unhealthy foods (BPOM RI, 2012).

Data from monitoring conducted by the Indonesian National Drug and Food Control Agency in 2007 found that $45 \%$ of snacks sold in elementary schools in Indonesia did not meet quality and safety standards because of biological contamination and contained hazardous chemicals such as formaldehyde, borax and rhodamin $\mathrm{B}$ in 
addition also contains food additives such as sodium benzoate and cyclamate which exceed safe limits. Data from the monitoring agency of POM published through Food Watch in 2009 revealed that in the main food group, $12.98 \%$ of the sample contained formalin, 9.74\% contained borax, and $32.61 \%$ contained Staphylococcus aureus which exceeded the threshold. In the snack group $16.06 \%$ of the sample contained formalin, and $27.78 \%$ of the sample contained the Total Plate Figures exceeding the threshold and in the beverage group, $69.03 \%$ of the samples contained E. colli (BPOM RI, 2014).

During this time, there are still many school snacks that are not guaranteed health and have the potential to cause poisoning. With so many foods containing dangerous chemicals on the market, school canteens, and food vendors around the school are important agents that can make students consume unhealthy foods. A survey in 220 districts and cities in Indonesia found that only $16 \%$ of schools were eligible for healthy canteen management (Suci, 20o9). Considering the important role of the canteen, the management of the canteen should receive attention from the school management and the local government. According to the Regulation of the Minister of Health of the Republic of Indonesia Number 1429 / MENKES / SK / XII / 2006 concerning Guidelines for Conducting School Environmental Health, that schools must have a canteen that meets the standards health. School stalls or canteens have at least a washing place for eating and drinking utensils, as well as washing hands with running water, a clean and closed food storage area, and a location that is at least 20 meters away from a temporary landfill site. But the results of research on healthy schools conducted by the Center for Physical Quality Development in 2007 in 640 schools in 20 provinces showed 40\% did not have a canteen, while of those who already had a canteen (60\%) $84.30 \%$ of the canteens did not meet health standards.

\section{SUBJECTS AND METHOD}

\section{Study Design}

This type of research is a qualitative descriptive study using a case study approach, which aims to get in-depth information about knowledge of attitudes and behaviors towards children's snack patterns in SD Negeri 6 Beji. This research was conducted at Beji 6 Public Elementary School in May 2019.

\section{Population and Sample}

The data used in this research was primary data. The informant in the study consisted of principals, teachers, school guards, elementary schools, canteen guards, and street food at SD Negeri 6 Beji.

\section{Study Instrumen}

The research instrument for retrieving research data is in-depth interviews, observation, and documentation.

\section{Validity}

To maintain the validity of the data and test the results of qualitative research, a data validity test was used using triangulation (Health Research Methodology, 2010):

\section{Triangulation of Sources}

Done by cross checking data with facts from other sources. These sources might be different informants, different research techniques to explore the same topic, or results from other sources and from the same research studies. The data must strengthen or contradict one another.

\section{Triangulation Method}

Done by using several methods in gathering data related to the research. In this study conducted in-depth interviews and observation and documentation. 


\section{RESULTS \\ 1. Informant Characteristics}

The informant is chosen by considering the information that will be obtained about the school policy that regulates the pattern of children's snacks. The informants in this study were 15 people consisting of two teachers with the principal as the key informant and the teacher of class II who was also in charge of the school health effort
(UKS). Eight students are students from grades II, III and IV of SD Negeri 6 Beji. The other two are the manager of the school canteen, who is his mother and son. Three people are street hawkers who are outside the school area, namely traders selling sachets, papeda snacks (egg base ingredients with a mixture of rolled sago flour) and milk drinks in glass bottles ready to drink.

Table 1. Distribution of Informants by gender

\begin{tabular}{|c|c|c|c|}
\hline Informant & Gender & $\mathbf{F}$ & Total \\
\hline \multirow[t]{2}{*}{ Teacher } & Male & - & \multirow[b]{2}{*}{2} \\
\hline & Female & 2 & \\
\hline \multirow[t]{2}{*}{ Student } & Male & 4 & \multirow{2}{*}{8} \\
\hline & Female & 4 & \\
\hline \multirow[t]{2}{*}{ Canteen Seller } & Male & 1 & \multirow[b]{2}{*}{2} \\
\hline & Female & 1 & \\
\hline \multirow[t]{2}{*}{ Seller outside } & Male & 2 & \multirow[b]{2}{*}{3} \\
\hline & Female & 1 & \\
\hline TOTAL & & & 15 \\
\hline
\end{tabular}

2. Knowledge of School Policies that Regulate Children's Snack Consumption

From the results of in-depth interviews conducted with two teachers at Beji $6 \mathrm{Pu}-$ blic Elementary School, there were differences of opinion between the Principal and the homeroom teacher who was also in charge of the UKS. According to the Principal, the policy regarding healthy canteens is known to all staff and teachers on the basis of the existence of routine food sample checks conducted by the health center every year.

"The policy on healthy canteens is already known and previously was given a letter about healthy snacks for children from the health department. Food checks have also been carried out in schools, although not often, approximately 1 time in 2 years. For training on healthy canteens for experts in schools has also never been done, which should be in the policy ".

The opposite was said by the home- room teacher who said that not all staff and teachers understood the inspection of food samples to be an indicator that health-based canteens should be implemented in schools. There are still those who think that it is just a routine work program from the local health center to ensure the safety of snacks consumed by children.

"Lack of information regarding current or current policies, known only by the health department regarding inspection of foods sold in the school canteen, and if there are foods that do not comply with the provisions of the health department, sales are prohibited in the school canteen. and it has been well followed by the school".

It is different with what is said by vendors who sell food outside of school. School policies that forbid students to spend outside snacks are actually already known to them, it's just that sometimes there are still many students who steal 
time and opportunities for snacks outside which then makes the traders can get a little income because the average selling is an income their main.

"There was a prohibition, but there are still those who violate it by staying out of school for snacks outside. if the prohibition of snacks outside the school is implemented, traders claim to object with the reason of lowering their daily income and going to other businesses ".

\section{Availability of Resources for the Implementation of Children's School Canteens}

According to the school principal and homeroom teacher, the resources highlighted were human resources namely the competence of the canteen guards. Both informants felt that there was still no training organized by the puskesmas in managing food in accordance with the indicators for implementing a healthy canteen at school. Besides that the canteen manager is also a senior manager so it will be easier to direct if there are food samples that are not suitable for the puskesmas test results.

"The canteen is currently guarded by 2 officers. However, according to previous information, training for canteen guards has never been carried out related to the implementation of healthy canteens by the health department. Parents in this case also have not been involved further, there are only a few who entrust food to be sold in the school cafeteria. The school urges canteen officials to only sell healthy snacks and pay attention to proper waste disposal both at the time of manufacture and at the time of serving. "

"There has not been a special recruitment of culinary experts for example to guard the canteen. The canteen officer is currently classified as a senior because there are already ahead of a number of lecturers. The health ministry also has no appeal regarding the training of school canteen guards. However, if the canteen is traced, it is still clean in terms of water sources, the way they are made and how they are served. "

The results of in-depth interviews conducted with students about the resources in the school canteen showed that they were more focused on the canteen infrastructure itself. Most feel the canteen still feels so narrow even though it has been renovated. For food sold in the canteen, the majority of children like it

\section{Attitudes towards School Policies that Regulate Children's Snack Con- sumption}

According to the two teachers who became informants, there was no prohibition for students not to eat snacks outside of school. The school also has not been firm to close the school gate during recess, closing the school gate only when it rains. The effort made is only an appeal to bring supplies and cutlery from each house with a more secure hygiene instrument as well as to avoid increasing plastic waste production.

"Since 3 years there has been an appeal to the children of students for snacks only in the school canteen. However, the school is not brave enough to firmly close the gate when learning and teaching activities because it will kill the business of outside hawker traders. The school gate will only be closed during recess if it is raining and children are prohibited from leaving the school. Children are also encouraged to bring supplies from home. Most basic, the school also urges the children to bring a place to eat (plates), spoons, and tumblers from home so that later they can be washed at home so that they are cleaner. But in practice there are still many shortcomings". 
The attitude taken by the school to traders outside the school is to hold a meeting between traders outside the school and the school and there has been an appeal regarding the application of healthy snacks. But the implementation is still a gradual process carried out by all traders. The health office has also conducted an examination of snacks outside the school. Found some dangerous foods that are forbidden to be sold again around the school.

"The school has invited traders a number of times. The traders are invited to dialogue about food manufacturing, serving, and even garbage disposal to keep the environment clean. Appeal to traders not to use cooking oil for frying more than 2 times, the use of plastic waste and disposal should also not be arbitrary. But for the presentation and manufacturing process let alone the use of oil gorang there are still traders who do not follow the appeal".

"Schools and health offices always pay attention to traders outside of school. The school has often held meetings with these traders and provided advice regarding healthy snacks and garbage disposal. The health office has also inspected food sold outside the school, and if dangerous food is found, it is prohibited to be sold again the same as the school canteen."

\section{Describe Supports and Difficul- ties in Implementing School Policies that Regulate Consumption of Chil- dren's Snacks at School}

Support received in the application of school policies to school canteens and healthy snacks regarding children's snack patterns is through health food checks carried out by the health department so as to prevent unhealthy foods being sold freely in the school environment.

"The health department checks every food sold both in the school canteen and outside the school. This more or less helps the school to reduce the list of unhealthy snacks that are in the school environment" Communication was carried out by the school regarding where the water used to sell refill water was from the factory refill water. Efforts by the school to establish communication with traders outside the school environment such as counseling were said to be almost non-existent or never by street vendors outside the school

"Never, only recorded ID cards there is no communication".

\section{DISCUSSION}

Food and snacks in schools is an issue that needs public attention, especially for parents, educators, and school managers. This is because snacks at school are very at risk of biological or chemical contamination that can interfere with children's health, both in the short term and long term. One of the things that needs to be the main concern is, food and snacks in schools contribute energy for school children by $36 \%$, protein by $29 \%$, and iron by $52 \%$. This is a big challenge for the government and school managers to be able to meet the nutritional intake of school students without having to eat snacks outside of school if possible (Suci, 2009).

\section{Discussion of Teacher and Princi- pal Interview Results}

a. Knowledge of policies governing the consumption of children's snacks

The school canteen procurement policy is understood by the Principal of Beji 6 Elementary School, as stated in PP Number 19 of 2005 concerning National Education Standards, article 42 paragraph 2 which states that each education unit must have facilities and infrastructure including a Canteen Room.

The regulation was then developed and made a program by the Ministry of National Education namely the School 
Children Snack Food Safety Development Program through the School Healthy Canteen in 2010. However, these policies and programs have not been evenly understood by the teaching team so as to make the implementation of healthy canteens in SDN Beji 6 less optimal.

The school in this case has coordinated with the local Health Service but only limited to examining food sold in the school canteen. The Principal and Teaching Team only focused on the limited space available for the school canteen so that the repair process had not been able to run until now.

Meanwhile, in the regulations on school canteen policies, it is stated that there are 7 steps to realize the folding of the school canteen in accordance with its role, for example in terms of canteen manager training, socialization to parents of students, and others. This should be the basis for the school to improve the existing school canteen and not have to wait for sufficient space first.

b. Availability of resources for the implementation of school canteens

SDN Beji 6 does not have experts for canteen management. At present, the school canteen is managed by 2 people who have never received training in school canteen management. That is temporary, for the creation of a school canteen that provides healthy and safe food, a trained manager is needed. This has become an obstacle for schools, because the local Health Office has also never held training for school canteen managers.

c. Attitudes toward school policies governing children's snack consumption

SDN Beji 6 has often coordinated with traders outside the school so that the traders sell food with a healthy and safe management and serving process that is supported by the inspection of snacks sold out- side the school.

However, when examined again this tends to show that schools do not yet have the courage to prohibit snacking students outside of school. The school has not yet focused on improving the management of the school canteen. This causes students to be increasingly difficult to prohibit snacks outside school.

d. Support and difficulties in implementing school policies that regulate consumption of children's snacks. If further analysis the constraints in the procurement of school canteens at SDN Beji 6 are internal and external.

Internal constraints were found that schools that did not yet have a commitment to realize the school canteen while already aware of the existence of the school canteen implementation policy to fulfill their role as a snack room for school children that embodied health messages and could determine the daily eating behavior of students by providing food for snacks. at school as a substitute for breakfast and lunch at home as well as snacks and drinks that are healthy, safe, and nutritious. This has not yet become the focus of schools which only take refuge in the unavailability of space for school canteens, while other matters are not fixed first. External constraints that occur are the number of traders outside the school because the location of the school is also close to the field (gathering place) so that it becomes difficult to act firmly by closing the school gates during teaching and learning activities. Another obstacle is the lack of training from the local health office to create canteen management experts who are also supported by the passivity of the school's attitude in this matter.

\section{Discussion of Results of Interviews with Students}

The choice of food and snacks is one form of health behavior. Factors that influence 
this behavior can be divided into 3 groups, namely factors related to food, personal factors, and socioeconomic factors in the context of food selection. Food related factors include nutrient content, as well as chemical and physical components of food. Personal factors include sensory perceptions, such as aroma, taste, and texture, as well as socioeconomic factors including price, brand, availability, and culture (Aprilia, 2011).

a. Knowledge of policies governing the consumption of children's snacks.

From 8 student informants interviewed in this study, as many as 6 students were given an allowance of $\mathrm{Rp} \mathrm{10,000,-} \mathrm{one}$ student was given an allowance of $\mathrm{Rp}$ 2,000 , and one other person was given a Rp 15,000 pocket. Two subjects stated that the allowance was not spent and the rest was saved, while most of the others spent the allowance. Of the 8 students who became the informants, 4 of whom like to buy snacks outside of school, and 4 others prefer to buy food and snacks in the school canteen. Pocket money that is routinely given to students can shape students' attitudes and perceptions that the allowance is their right. Lack of advice and guidance from parents about the use of pocket money can encourage students to use it freely, and will affect the habits of snacks in school-age children (Apriliani, 2011).

Based on the results above, it can be seen that the allowance does not affect the choice of food and snacks consumed by students. This can be influenced by several factors. The characteristic of elementary school students is that they like to imitate the people around them, including parents, teachers, and peers. The behavior that often arises is imitating peers. The average elementary school student considers the taste of food and snacks to be more important than the nutritional content of the food. In addition, the availability of healthy food and snacks is one of the important factors in students' actions when choosing food and snacks.

b. Availability of resources for the implementation of school canteens

From observations made during the study, the school canteen seemed too small to serve students who were shopping. This has become one of the factors influencing the selection of snacks for 6 Beji Elementary School students. Some students who became informants said that the reason they bought food outside of school was because the canteen room felt cramped during break time.

c. Availability of resources for the implementation of school canteens

From the observations made during the study, the school canteen seemed too small to serve students who were shopping. This has become one of the factors influencing the selection of snacks for 6 Beji Elementary School students. Some students who became informants said that the reason they bought food outside of school was because the canteen room felt cramped during recess.

d. Attitudes toward school policies governing children's snack consumption.

Based on research conducted by Apriliani (2011), the frequency of bringing lunch to students is known to have a relationship with the choice of food and snacks at school, where the more frequent the frequency of carrying lunch, the choice of food and student snacks at school the better. From the results of interviews conducted on students who became informants, almost all brought lunch from home, but the frequency of carrying lunch only occasionally (1-3 times / week).

This causes students to continue to buy food and snacks while at school. In 
addition, SD Negeri 6 Beji also has two breaks, namely at 09:30 and 12.00. Students who bring lunch to school are known to consume lunch at one break, and buy food and other snacks at rest time. Bringing supplies to elementary school students can provide benefits that can prevent students from hunger disorders. When students have brought lunch to school, students will tend to consume lunches brought from home, so as to prevent children from buying snacks (Handayani, 2009).

e. Attitudes toward school policies governing children's snack consumption

Based on research conducted by Apriliani (2011), the frequency of bringing lunch to students is known to have a relationship with the selection of food and snacks at school, where the more often the frequency of carrying lunch, the choice of food and snacks for students at school the better. From the results of interviews conducted on students who became informants, almost all brought lunch from home, but the frequency of carrying lunch only occasionally (1-3 times / week).

This causes students to continue to buy food and snacks while at school. In addition, SD Negeri 6 Beji also has two breaks, namely at 09:30 and 12.00. Students who bring lunch to school are known to consume lunch at one break, and buy food and other snacks at rest time. Bringing supplies to elementary school students can provide benefits that can prevent students from hunger disorders. When students have brought lunch to school, students will tend to consume lunches brought from home, so as to prevent children from buying snacks (Handayani, 2009).

f. Support and difficulties in implementing school policies that regulate consumption of children's snacks
From observations during the study, the school fence remained open, there were no teachers or school guards standing guard around the gate and students were free to leave the school gate during recess. This directly affects the behavior of students who are free to buy snacks outside of school.

\section{Discussion of Interview Results with School Canteen Traders}

When we asked some of these things to the traders of Depok Beji SDN 6 Canteen School regarding school policies governing the consumption of snacks, researchers only got some information about the policies adopted at the depok 6 Beji public elementary school, indeed there were though the implementation was not in accordance with what delivered like a canteen must always be clean and healthy, packaged food that is sold must also be registered with the BPOM agency and the processing of fast food must be hygienic and nutritious both in the processors and the equipment used and it does not comply with the provisions of Law No. 12 of 2012 about food.

\section{Discussion of the Results of Inter- views with Street Food Traders}

Based on the results of our study in-depth interviews with traders who sell outside the school, outside the Beji 6 SDN environment, the data shows that they have been selling there for 14 years, 5 years and 6 years so that it has become their permanent job so far, they selling from morning to afternoon those that are until the afternoon. Buyers are not only school children but also small children who play around the school and mothers who come to school to deliver their children.

The sachet seller claimed that he had been selling 14-year-old powdered beverage with various flavors, brewed with a little hot water and then poured ice cubes 
in disposable plastic cups, selling from morning to afternoon after that, going around again to peddle their wares, the third informant, namely papeda traders, has been selling there for 6 years from morning to evening, consumers are not just school children but also mothers who deliver their children.

Raw materials from their sales tend to be simple, sellers of sachets only supply powdered sachets of various flavors and brands that are bought from the market, while sellers of packaged milk drinks take their merchandise at collectors around Margonda. Papeda buys ingredients such as sago, eggs, and seasonings on the market. The food vendors outside claimed there had never been counseling from the school. This is a record for us because there should be routine counseling from the school related to many things about snacks for school children such as the variety of sales, ingredients, how to process it and its hygiene.

\section{REFERENCES}

Aprilia BA (2011). Faktor yang berhubungan dengan pemilihan makanan jajanan pada anak sekolah dasar (Factors Associated with Selection of Snack Foods in Primary School Children). Universitas Diponegoro, Semarang

Badan Pengawas Obat dan Makanan. (2012). Penyerahan sertifikat piagam bintang keamanan pangan di kantin sekolah (PBKP-KS) (submission of the food safety star certifycate in the school canteen (pbkpks). www.pom.go.id/mobile/index.php/view/berita/2345/Penyerahan -Sertifikat-Piagam-Bintang-Keamanan-Pangan-di-Kantin-Sekolah-PBKP-KS.html

BPOM (2017). Pangan jajan anak sekolah (pjas) harus aman dari bahan berbahaya (school children snack food (pjas) must be safe from hazardous materials). https://www.pom.go.id/new/view/more/berita/13375/Pan gan-Jajan-Anak-Sekolah--PJAS-Harus-Aman-dari-Bahan-Berbahaya- .html.

Handayani N. 2009. Peran orang tua, sekolah, dan pedagang pada makanan jajanan anak (The role of parents, schools, and traders in children's snacks). Accessed http://www.jurnal.pdii.lipi.go.id

Hang CM, Lin W, Yang HC, Pan WH (2007). The relationship between snack intake and its availability of $4^{\text {th }}$ $6^{\text {th }}$ graders in Taiwan. Asia Pac J Clin Nutr. 16: 547-553

Ministry of National Education (2010). Materi kantin sehat di sekolah (healthy canteen material in schools). Pusat Pengembangan Kualitas Jasmani Kementerian Pendidikan Nasional. Jakarta.

Peraturan Menteri Kesehatan Republik Indonesia nomor 1168/menkes/per/X/1999 tentang bahan tambahan makanan (1999) (regulation of the minister of health of republic of Indonesia number 1168/Menkes/Per/X/1999 concerning Food Additives). Jakarta.

Perdana (2018). Kantin sekolah diusulkan masuk kriteria akreditasi sekolah (school canteen proposed to enter the school accreditation criteria). https://radarsolo.jawapos.com/read/2 018/11/o6/1021134/kantin-sekolahdiusulkan-masuk-kriteria-akreditasisekolah

Suci, Tyas ES (2009). Gambaran perilaku jajan murid sekolah dasar di Jakarta (overview of snacking behavior of elementary school students in Jakar- 
ta): $29-38$.

Undang-Undang Republik Indonesia Nomor 12 Tahun 2012 Tentang Pangan. Jakarta. Undang-Undang Republik Indonesia Nomor 7 Tahun 1996 Tentang Pangan (1996). Bogor: M-Brio Press.
Wire PR (2019). Kepala badan POM apresiasi 14 sekolah penerima PBKP-KS (Head of POM appreciation 14 school receiver PBKP-KS). https://antaranews.com/amp/berita/814099/kepala-badan-pom-apresiasi-14-sekolah-penerima-pbkp-ks 